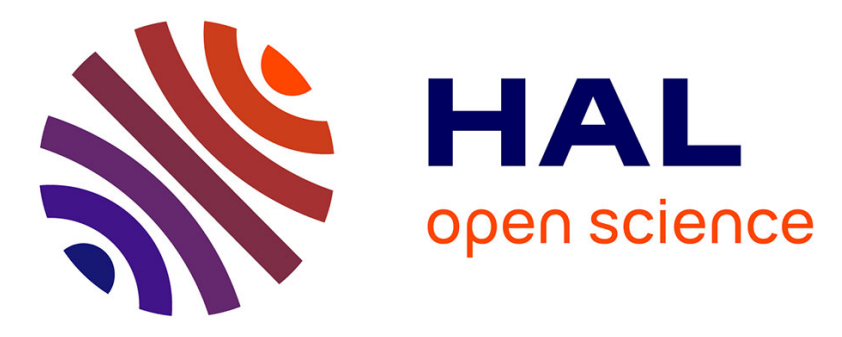

\title{
Packageless acoustic wave sensors for wireless body-centric applications
}

Sami Hage-Ali, Omar Elmazria, Gaël Pierson, Richard Kouitat Njiwa, Thierry Aubert, Moïse Deroh, Florian Bartoli, Abdelkrim Talbi

\section{- To cite this version:}

Sami Hage-Ali, Omar Elmazria, Gaël Pierson, Richard Kouitat Njiwa, Thierry Aubert, et al.. Packageless acoustic wave sensors for wireless body-centric applications. IEEE Sensors, Oct 2016, Orlando, United States. pp.1-3, 10.1109/ICSENS.2016.7808870 . hal-01628935

\section{HAL Id: hal-01628935 \\ https://hal.science/hal-01628935}

Submitted on 17 Jan 2020

HAL is a multi-disciplinary open access archive for the deposit and dissemination of scientific research documents, whether they are published or not. The documents may come from teaching and research institutions in France or abroad, or from public or private research centers.
L'archive ouverte pluridisciplinaire HAL, est destinée au dépôt et à la diffusion de documents scientifiques de niveau recherche, publiés ou non, émanant des établissements d'enseignement et de recherche français ou étrangers, des laboratoires publics ou privés. 


\section{Packageless acoustic wave sensors for wireless body-centric applications}

\author{
Sami Hage-Ali, Omar Elmazria, Gaël Pierson, \\ Richard Kouitat \\ Institut Jean Lamour UMR 7198 \\ Université de Lorraine - CNRS \\ 54506 Vandœuvre-lès-Nancy, France \\ sami.hage-ali@univ-lorraine.fr
}

\author{
Thierry Aubert \\ Laboratoire SYMME \\ Université Savoie Mont Blanc \\ 74944 Annecy-le-Vieux, France
}

\begin{abstract}
This paper describes the investigation of the potential of $\mathrm{Al}_{2} \mathrm{O}_{3} / \mathrm{ZnO} / \mathrm{LiNbO}_{3}$ packageless structures for bodycentric acoustic wave sensor applications, which are investigated numerically and experimentally.
\end{abstract}

Keywords-Surface acoustic wave; waveguiding layer acoustic wave; sensor; wireless; packageless

\section{INTRODUCTION}

Surface Acoustic Wave (SAW) devices are widely used as filters, resonators or delay lines in electronic systems for a wide range of applications: mobile communications, radars, as stable resonators for clock generation. The resonance frequency and the signal transmission delay of SAW devices may depend on the physical parameters of the environment, and SAW devices are increasingly used as sensors for a large variety of parameters: gas, pressure, force, temperature, strain, radiation, etc.

The SAW-based sensors have the advantage to be fully passive (battery-less) and can be interrogated using wireless techniques. That is why SAW devices are particularly useful in so-called "harsh" environments like radiative or high temperature environment [1]. One can argue that the human body is also a harsh environment due the potential high acoustic and electromagnetic loss in wireless sensors.

In any case, the packaging of the SAW sensor is critical and often challenging. An elegant solution is to use "packageless" Waveguiding Layer Acoustic Wave (WLAW) devices [2-6]. WLAW devices allow the confinement of the acoustic wave using a combination of low acoustic velocity layer stacked between two high acoustic velocity layers (See Fig. 1), thus removing the need of a bulky package.

In this communication, we study numerically and experimentally a $\mathrm{Al}_{2} \mathrm{O}_{3} / \mathrm{ZnO} / \mathrm{LiNbO}_{3}$ (LN-128 Y-X cut) structure and investigate its use for body-centric applications, especially for "epidermal electronics", i.e. skin- printed

This work was supported partly by Région Lorraine and European FEDER funding (Appel d'Offre Région )

\author{
Moïse Deroh, Florian Bartoli, Thierry Aubert \\ LMOPS EA 4423 \\ CentraleSupélec - Université de Lorraine \\ 57070 Metz, France
}

\author{
Abdelkrim Talbi \\ Joint International Laboratory LIA LICS/LEMAC \\ IEMN UMR CNRS 8520 \\ ComUE Lille Nord de France, ECLille \\ 59651 Villeneuve d'Ascq, France
}

electronics. In order to assess experimentally the confinement of the acoustic wave in a flexible/on-skin electronics context, we put the $\mathrm{LN} / \mathrm{ZnO} / \mathrm{Al}_{2} \mathrm{O}_{3}$ structure in contact with Solaris [7] (Smooth-On Inc., USA), a modified silicone elastomer that closely matches the mechanical properties of the skin $\left(\mathrm{E}_{\text {Young }}=\right.$ $\sim 50 \mathrm{kPa}$ ). We investigated the increase of the insertion loss of a delay line across the spectrum in these conditions, to see if the presence of the elastomer generates additional losses.

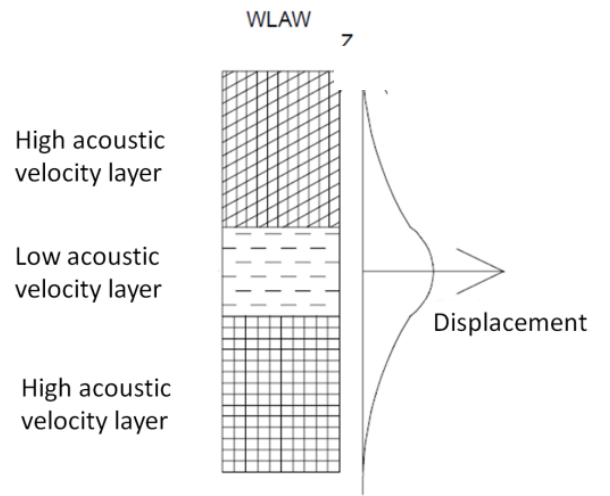

Fig 1: WLAW device principle. Adapted from [2]

\section{FEM MODELLING}

Initial modelling has been performed using a commercial FEM Software (Comsol Multiphysics v4.3b). We modeled a 2D infinite periodic interdigital transducer (IDT) and computed the particle displacements for a $\mathrm{Al}_{2} \mathrm{O}_{3}$ $(20 \mu \mathrm{m}) / \mathrm{ZnO}(2 \mu \mathrm{m}) / \mathrm{LN}-128$ structure (see Fig. 2$)$ in order to study its eligibility for WLAW operation. As we can see in Fig $2 \mathrm{~b}$, the particle displacement at the surface of $\mathrm{Al}_{2} \mathrm{O}_{3}$ (at $22 \mu \mathrm{m}$ "height") is negligible, thus validating this structure numerically. However this alumina thickness is not very practical for experiments and we chose a thickness of $8 \mu \mathrm{m}$ for $\mathrm{Al}_{2} \mathrm{O}_{3}$, expecting a dual operation: non-confined waves for the fundamental mode and confined waves for the higher order harmonics. 


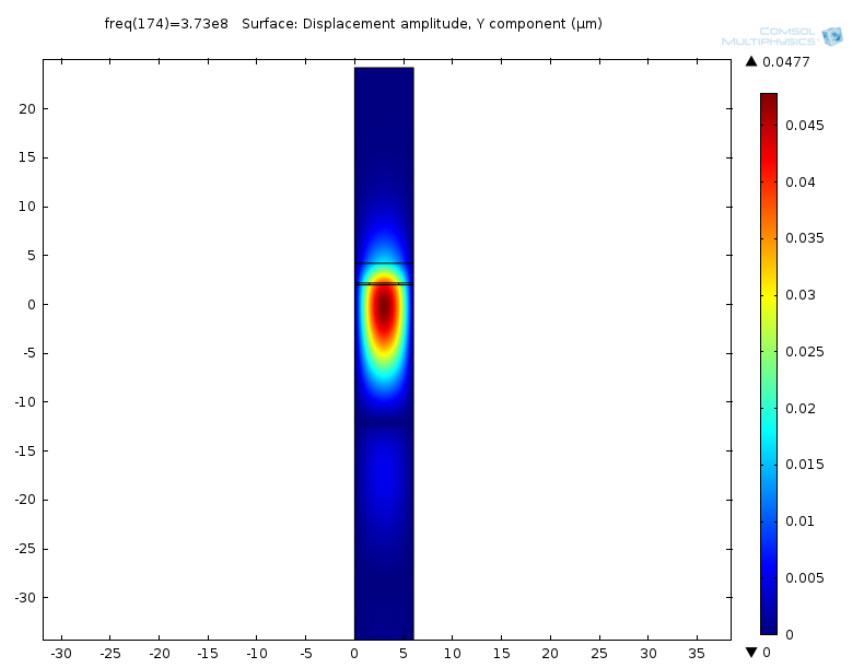

(a)

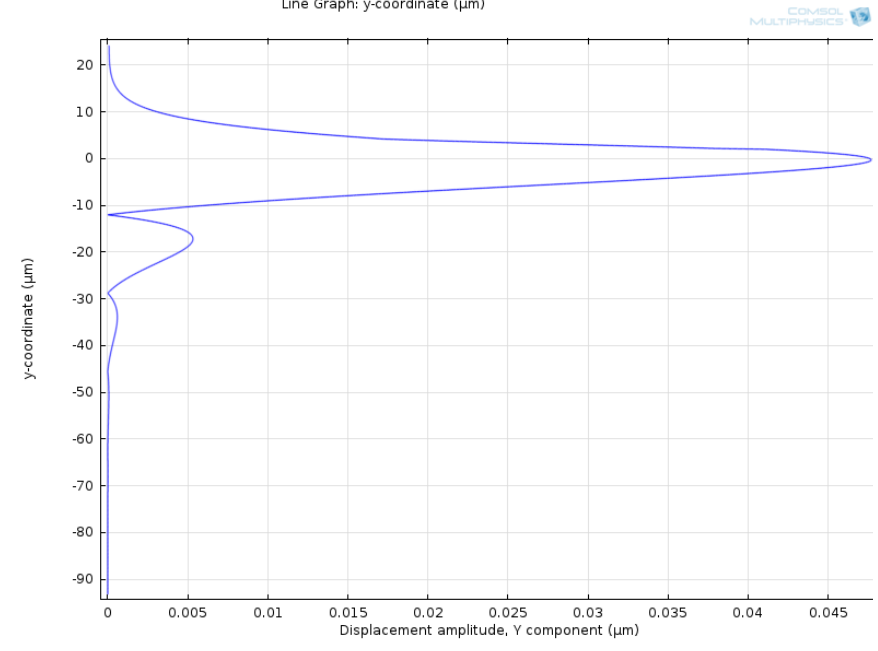

(b)

Fig. 2: Wave displacements in a $\mathrm{Al}_{2} \mathrm{O}_{3}(20 \mu \mathrm{m}) / \mathrm{ZnO}$ $(2 \mu \mathrm{m}) / \mathrm{LN}-128$ structure in $2 \mathrm{D}$ (a) and $1 \mathrm{D}(\mathrm{b})$ formats. The 0 $\mu \mathrm{m}$ reference is at the interface between $\mathrm{LN}$ and $\mathrm{ZnO}$ layers.

\section{MICROFABRICATION AND CHEMICAL / STRUCTURAL ANALYSIS}

A layer of $70 \mathrm{~nm}$ of aluminum was deposited on a LN-128 Y-X cut wafer by RF magnetron sputtering. A SAW delay line with $12 \mu \mathrm{m}$ periodicity was patterned by photolithography using S1813 positive photoresist, and wet etching. $2 \mu \mathrm{m}$ of $\mathrm{ZnO}$ were deposited using RF magnetron sputtering, a 4-in $\mathrm{ZnO}$ target and additional oxygen $\left(\mathrm{O}_{2} 8 \mathrm{sccm}\right.$, Ar $8 \mathrm{sccm}$, $\left.2 \times 10^{-3} \mathrm{mbar}\right), 100^{\circ} \mathrm{C}, 100 \mathrm{~W}$.

Alumina deposition by RF magnetron sputtering using a 4in $\mathrm{Al}$ target has been optimized to ensure maximum deposition speed $\left(\mathrm{O}_{2}, 3.5 \mathrm{sccm}\right.$, Ar $\left.16.5 \mathrm{sccm}, 2 \times 10^{-3} \mathrm{mbar}\right), 300 \mathrm{~W}$, no heating. The result is an amorphous layer (as confirmed by TEM and electron diffraction), with nanogranular structure. EDX analysis confirmed a $40 \% \mathrm{Al}$ and $60 \% \mathrm{O}_{2}$ ratio, i.e. a perfect alumina stoichiometry.

A $8 \mu \mathrm{m}$ alumina layer was deposited using these parameters. In order to open the connection pads for RF measurements, these were protected using AZ9260 photoresist and Kapton tape, which were removed after $\mathrm{ZnO}$ and $\mathrm{Al}_{2} \mathrm{O}_{3}$ depositions. The cross section SEM picture of the $\mathrm{Al}_{2} \mathrm{O}_{3} / \mathrm{ZnO} / \mathrm{Si}$ control sample is shown in Fig. $3 \mathrm{a}$ and the final device is depicted in Fig. $3 \mathrm{~b}$.

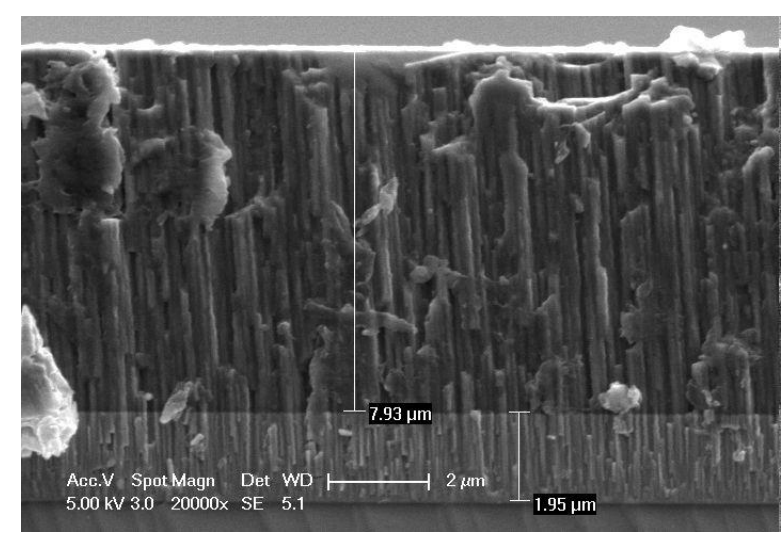

(a)

$$
\begin{array}{cc}
\text { Zone coated with } \mathrm{ZnO} & \text { Tested delay } \\
\text { and } \mathrm{Al}_{2} \mathrm{O}_{3} & \text { line }
\end{array}
$$

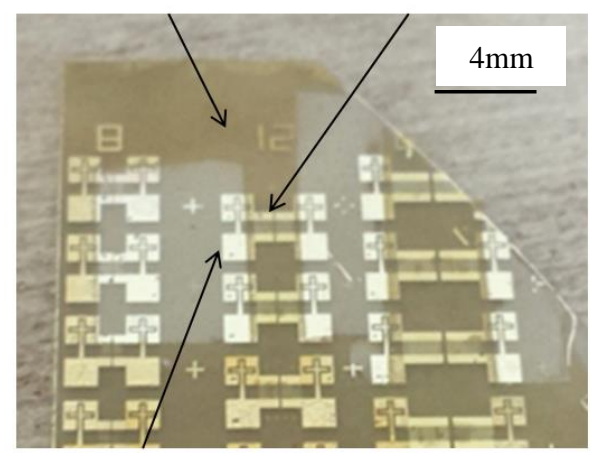

Connecting pad

(b)

Fig 3: (a) Cross-section SEM picture of the $\mathrm{Al}_{2} \mathrm{O}_{3} / \mathrm{ZnO} / \mathrm{Si}$ control sample (b) Fabricated delay line

\section{EXPERIMENTAL RF CHARACTERIZATIONS}

The AW delay line was characterized using an Agilent 5061B network analyzer and SOLT calibration in 3 configurations:

a: before $\mathrm{ZnO}$ and $\mathrm{Al}_{2} \mathrm{O}_{3}$ depositions (regular SAW device)

b: after $\mathrm{ZnO}$ and $\mathrm{Al}_{2} \mathrm{O}_{3}$ depositions

c: with added Solaris elastomer on top of it

These configurations are depicted in Fig 4(i)

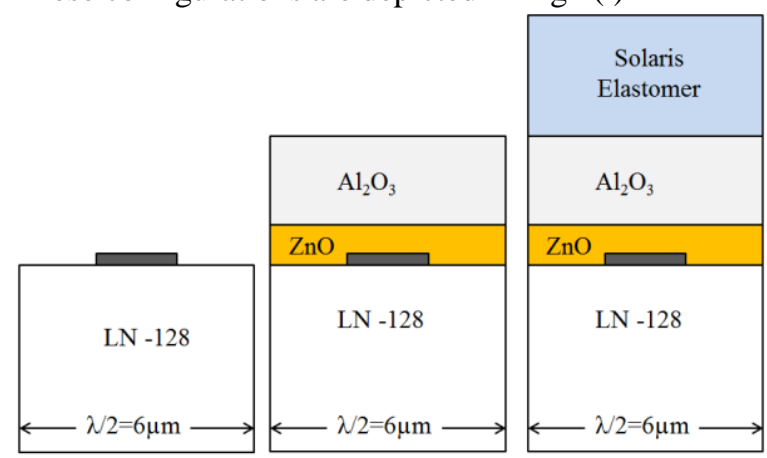

(a)

(b)

(c)

(i) 


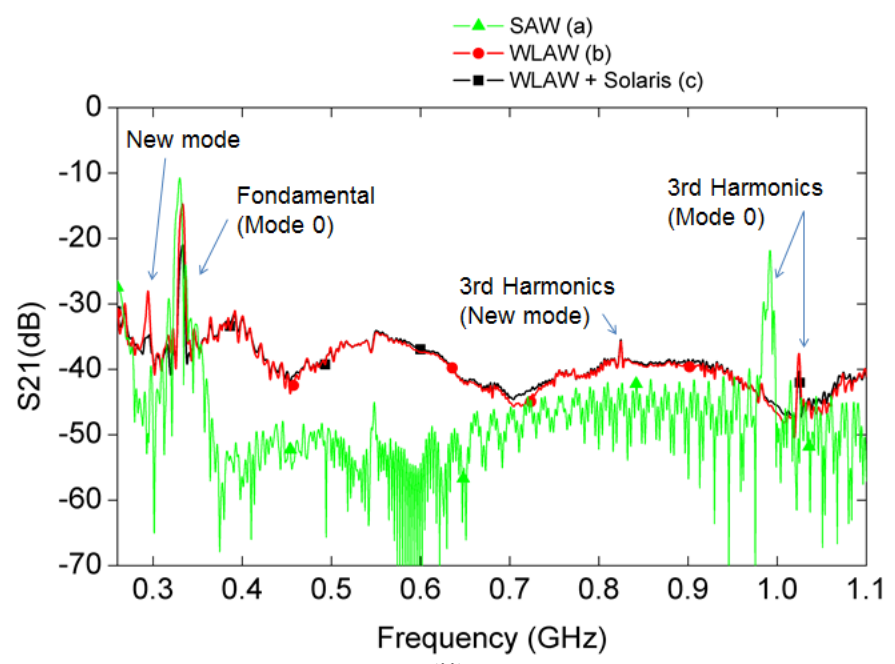

(ii)

Fig 4: (i) Measured configurations

(a) IDT/LN

(b) $\mathrm{Al}_{2} \mathrm{O}_{3}(8 \mu \mathrm{m}) / \mathrm{ZnO}(2 \mu \mathrm{m}) / \mathrm{IDT} / \mathrm{LN}-128$

(c) Solaris $(1 \mathrm{~mm}) / \mathrm{Al}_{2} \mathrm{O}_{3}(8 \mu \mathrm{m}) / \mathrm{ZnO}(2 \mu \mathrm{m}) / \mathrm{IDT} / \mathrm{LN}-128$

(ii) Frequency response of the 3 configurations

TABLE I. Modes, harmonics and insertion loss increase between $\mathrm{a}, \mathrm{b}$ and $\mathrm{c}$ configurations

\begin{tabular}{|c|c|c|c|c|c|}
\hline \multicolumn{2}{|c|}{$\begin{array}{c}\text { Mode } \\
\text { (Harmonics) }\end{array}$} & $\begin{array}{c}0 \\
\text { (Fund.) }\end{array}$ & $\begin{array}{c}0 \\
\left(3^{\text {rd }} \text { Har. }\right)\end{array}$ & $\begin{array}{l}\text { New } \\
\text { mode } \\
\text { (Fund.) }\end{array}$ & $\begin{array}{c}\text { New } \\
\text { mode } \\
\left(3^{\text {rd }} \text { Har. }\right)\end{array}$ \\
\hline \multicolumn{2}{|c|}{$\begin{array}{l}\text { Frequencies } \\
(\mathrm{MHz})\end{array}$} & 330 (a) & 991 (a) & 294 (b) & $825(b, c)$ \\
\hline$S_{21}(d B)$ & $\begin{array}{l}\text { (a) } \\
\text { (b) } \\
\text { (c) }\end{array}$ & $\begin{array}{r}-8.7 \\
-13.9 \\
-20.2\end{array}$ & $\begin{array}{l}-19.1 \\
-36.9 \\
-39.0\end{array}$ & $\begin{array}{l}\text { N/A } \\
-26.2 \\
-34.1\end{array}$ & $\begin{array}{c}\text { N/A } \\
-33.83 \\
-33.72\end{array}$ \\
\hline \multicolumn{2}{|c|}{$\Delta S_{21} a->b$} & -5.2 & -17.8 & N/A & N/A \\
\hline \multicolumn{2}{|c|}{$\Delta S_{21} b->c$} & -6.3 & -2.1 & -7.9 & 0.11 \\
\hline
\end{tabular}

Fig.4 (ii) depicts the different frequency responses of configurations $\mathrm{a}, \mathrm{b}$ and $\mathrm{c}$, and the different modes/harmonics. As expected, there is an increase of the insertion loss between the 3 configurations. A new mode with a fundamental at 294 $\mathrm{MHz}$ and a $3^{\text {rd }}$ harmonic at $825 \mathrm{MHz}$ appears, after $\mathrm{ZnO}$ and $\mathrm{Al}_{2} \mathrm{O}_{3}$ depositions.

To get a clearer picture of the results, the modes/harmonics, insertion loss and the increase of the insertion loss between configurations are summarized in Table 1.
It appears that the wave is not confined at both fundamental frequencies of the two modes, since the contact with Solaris generate 6 to $8 \mathrm{~dB}$ additional loss. The wave at the $3^{\text {rd }}$ harmonic of the mode 0 at $1024 \mathrm{MHz}$ seems more confined since the contact with Solaris adds only $2.1 \mathrm{~dB}$.

More interesting is that the wave at the $3^{\text {rd }}$ harmonic of the "new" mode seems fully confined with virtually no change of insertion loss with added Solaris.

\section{DISCUSSION, CONCLUSION AND PERSPECTIVES}

Experimental evidence of a confined acoustic wave has been found in a $\mathrm{LN} / \mathrm{IDT} / \mathrm{ZnO} / \mathrm{Al}_{2} \mathrm{O}_{3}$ which is promising for on and intra-body acoustic wave sensors.

Additional modelling and elastic parameter measurements need to be performed.

\section{ACKNOWLEDGMENT}

The authors would like to thank Sylvie Migot at Institut Jean Lamour for the TEM/EDX characterizations, as well as Laurent Badie and Gwladys Lengaigne at Minalor platform at Institut Jean Lamour for the help with the microfabrication.

\section{REFERENCES}

[1] T. Aubert, O. Elmazria and B. Assouar, "Wireless and batteryless surface acoustic wave sensors for high temperature environments," Proc. of the 9th Inter. Conf. on Electronic Measurement \& Instruments (ICEMI), 2009, pp. 2-890-898.

[2] K. Bhattacharjee, A. Shvetsov and S. Zhgoon, "Packageless SAW Devices with Isolated Layer Acoustic Waves (ILAW) and Waveguiding Layer Acoustic Waves (WLAW)," IEEE International Frequency Control Symposium, 2007 Joint with the 21 st European Frequency and Time Forum., pp. 135-140, 2007

[3] Elmazria O, Zhgoon S, et al. AlN/ZnO/Diamond structure combining isolated and surface acoustic waves. Appl Phys. Lett, 95, pp. 233503(13), 2009.

[4] Legrani O, Elmazria O, Zhgoon S, et al. AlN/ZnO/Si Structure: a Packageless Solution for Acoustic Wave Sensors. IEEE Sensors Journal, 13, pp. 487-491, 2013.

[5] Legrani O, Elmazria O, Bartasyte A, et al. AlN/IDT/AlN/Sapphire as Packageless Structure for SAW Applications in Harsh Environments. In: Proc. IEEE IU Symp, pp : 2102- 2105, Dresden, 2012.

[6] Legrani O, Elmazria O, Pigeat P, et al. Deposition of Crack-Free $30 \mu \mathrm{m}$ AlN on IDT/ZnO/Si for Wave Guiding Layer Acoustic Wave Applications. In: Proc. IEEE IU Symp., pp. 2313-2316, Orlando, 2011.

[7] X. Huang, Y. Liu, H. Cheng, W.-J. Shin, J. A. Fan, Z. Liu, C.-J. Lu, G.W. Kong, K. Chen, D. Patnaik, S.-H. Lee, S. Hage-Ali, Y. Huang and J. A. Rogers, "Materials and Designs for Wireless Epidermal Sensors of Hydration and Strain," Adv. Funct. Mater., vol. 24, no. 25, pp. 38463854,2014 